\title{
Chronic NMDA Antagonism Impairs Working Memory, Decreases Extracellular Dopamine, and Increases D, Receptor Binding in Prefrontal Cortex of Conscious Monkeys
}

\author{
Hideo Tsukada', Shingo Nishiyama', Dai Fukumoto', Kengo Sato', Takeharu Kakiuchi' and \\ Edward F Domino*,2 \\ 'Central Research Laboratory, Hamamatsu Photonics K.K., Shizuoka, Japan; ${ }^{2}$ Department of Pharmacology, University of Michigan, Ann Arbor, \\ MI, USA
}

\begin{abstract}
This study demonstrates that dizocilpine (MK-80I), a noncompetitive N-methyl-D-aspartate (NMDA) receptor antagonist, impairs working memory of conscious behaving monkeys. In addition, acute and chronic MK-80I produces different effects on $D_{1}$ and $D_{2}$ receptor binding in prefrontal cortex (PFC). Extrastriatal neocortical receptor $D_{1}\left(D_{1} R\right)$ and $D_{2}\left(D_{2} R\right)$ binding were assayed by [ ' $\mathrm{C}] \mathrm{NNCI} 12$ and [ ' C]FLB457, respectively, using high-specific radioactivity and a specially designed monkey positron emission tomograph (PET). Acute single dose $(0.03,0.1$, and $0.3 \mathrm{mg} / \mathrm{kg})$ i.v. administration of MK-80I resulted in dose-related impairment of working memory performance of an oculomotor delayed response (ODR) task. There was no impairment of performance of a visually guided saccade (VGS) task with low doses of 0.03 and 0.1 , but it was depressed with $0.3 \mathrm{mg} / \mathrm{kg}$. Chronic daily MK-80I (0.03 mg/kg, i.m., b.i.d. for 13 days) induced impaired ODR task performance with no effect on the VGS task. Although acute single doses of MK-80 I caused no significant changes in [ ' $\mathrm{C}] \mathrm{NNCI} \mid 2$ binding to PFC $D_{1} \mathrm{R}$, chronic daily treatment increased binding about $\mid 4 \%(P<.05)$. Acute MK-80I dose-dependently decreased [ ' C]FLB457 binding about 35\% $(P<.0 \mathrm{I})$ to PFC $D_{2} \mathrm{R}$; chronic treatment had no significant effect. Microdialysis analyses demonstrated that acute single doses of $\mathrm{MK}-80 \mathrm{I}$ ( 0.03 and $0.1 \mathrm{mg} / \mathrm{kg}$ ) increased extracellular glutamate and dopamine (DA) levels in PFC. Chronic MK-80I gradually lowered glutamate and DA levels in PFC. The results demonstrate in conscious, unanesthetized primates that MK-80I induces impairment of PFC function, as measured by working memory performance. Furthermore, in response to lowered levels of DA in PFC, $D_{1} R$ binding is increased, whereas $D_{2} R$ binding is not.

Neuropsychopharmacology (2005) 30, I86 I- | 869. doi: I0.1038/sj.npp. I300732; published online 20 April 2005
\end{abstract}

Keywords: prefrontal cortex; positron emission tomography; microdialysis; working memory; NMDA; dopamine D, receptors; dopamine $\mathrm{D}_{2}$ receptors; monkey brain

\section{INTRODUCTION}

Working memory, which is the brief retention of internalized information to guide behavior, is known to be related to the prefrontal cortex (PFC) function (GoldmanRakic, 1987). Noncompetitive $N$-methyl-D-aspartate (NMDA) receptor antagonists, MK-801, ketamine, and phencyclidine, bind to an ion channel associated with the NMDA receptor (Thomson et al, 1985; Fagg, 1987) and cause impaired cognitive function including working memory performance in healthy humans (Javitt and Zukin,

\footnotetext{
*Correspondence: Dr EF Domino, Department of Pharmacology, University of Michigan, Ann Arbor, MI 48109-0632, USA, Tel: + 734 764 9II5, Fax: + 734763 4450, E-mail: efdabcde@umich.edu Received 16 September 2004; revised 10 February 2005; accepted 14 February 2005

Online publication: 3 March 2005 at http://www.acnp.org/citations/ Npp030305040428/default.pdf
}

1991; Krystal et al, 1994; Malhotra et al, 1996; Jentsch and Roth, 1999).

NMDA receptors are known to interact with the central dopaminergic system (Roberts and Anderson, 1979; Carter et al, 1988; Krebs et al, 1991; Morari et al, 1993; Youngren et al, 1993; Tsukada et al, 2000b, 2001b). Dopamine (DA) innervation of PFC is considered to be highly responsive to NMDA receptor antagonists (Deutch et al, 1987; Bowers and Morton, 1994; Hondo et al, 1994; Carlezon and Wise, 1996; Verma and Moghaddam, 1996; Jentsch et al, 1997a). The effect of noncompetitive NMDA receptor antagonists on DA metabolism is more enhanced in the mesocorticolimbic dopaminergic system than in the nigrostriatal dopaminergic system (Deutch et al, 1987; Rao et al, 1990). These modulations of PFC DA may be relevant to the psychotic effects of NMDA receptor antagonists, and these responses are, in part, inhibited by blocking dopaminergic transmission (Murray and Horita, 1978; Fessler et al, 1979). 
A very large body of data supports the hypothesis that chronic NMDA receptor antagonism reduces extracellular DA levels, modulates DA neurotransmission in prefrontal cortex (PFC), and alters working memory (for a review, see Jentsch and Roth, 1999). Although data supporting this hypothesis are extensive, they are fragmented with some findings in animals, both in vivo and ex vivo, and others in humans.

Positron emission tomography (PET) noninvasively measures the neuroanatomical distribution of radiolabeled DA-specific ligands in the living brain. However, the region of interest (ROI) has been limited to the striatum due to the lack of suitable labeled compounds for extrastriatal regions with a low density of DA neuronal terminals (Hall et al, 1988; Lidow et al. 1989). $\left[{ }^{11} \mathrm{C}\right] \mathrm{NNC1} 12$ (Halldin et al, 1998) and $\left[{ }^{11} \mathrm{C}\right] \mathrm{FLB} 457$ (Halldin et al, 1995) have been developed to assess the extrastriatal neocortical receptor $D_{1}\left(D_{1} R\right)$ and $D_{2}\left(D_{2} R\right)$, respectively. Recent PET studies have suggested the dysfunction of the extrastriatal dopaminergic system in schizophrenic patients (Okubo et al, 1997; Abi-Dargham et al, 2002; Suhara et al, 2002).

The purpose of the present research is to provide definitive in vivo data in subhuman primates (monkeys) using multidisciplinary methodologies that NMDA antagonism by dizocilpine (MK-801) affects all three variables as currently hypothesized. The results obtained provide the basis for further studies of normal brain function and its alterations in stress, mental disease, such as schizophrenia, and drug abuse with ketamine and phencyclidine (PCP).

\section{MATERIALS AND METHODS}

\section{Animals, Drugs, and Colocalization}

Eight young-adult male rhesus monkeys (Macaca mulatta) weighing from 5.5 to $7.0 \mathrm{~kg}$ were used in these studies. The monkeys were maintained and handled in accordance with the recommendations of the US National Institutes of Health and the guidelines of the Central Research Laboratory, Hamamatsu Photonics. Magnetic resonance images (MRI) of each monkey under pentobarbital anesthesia were obtained with a Toshiba MRT-50A/II (0.5 T, Toshiba Medical Corporation, Tokyo, Japan) for the purposes of brain colocalization. PET data were collected on a high-resolution PET scanner (Hamamatsu SHR-7700) as described below. PET images were generated by summation of image data from 37 to $64 \mathrm{~min}$ after injection. The stereotactic coordinates for PET and MRI were coregistered based on the orbitomeatal (OM) line. A specially designed head holder was used to restrict monkey head movements as described in our publications referred below.

For the acute study, $30 \mathrm{~min}$ before injection of $\left[{ }^{11} \mathrm{C}\right] \mathrm{NNC} 112$ or $\left[{ }^{11} \mathrm{C}\right] \mathrm{FLB} 457, \mathrm{MK}-801$ in doses of 0 (saline), $0.03,0.1$, and $0.3 \mathrm{mg} / \mathrm{kg}$ was administered i.v. at 0900 hours. After 1-2 weeks, for the chronic daily study, the lowest dose of $0.03 \mathrm{mg} / \mathrm{kg}$ of MK-801 was given i.m. b.i.d. at 0900 and 1700 hours for 13 days. On the 7th and 14th day after the beginning of chronic administration, microdialysis analyses of DA and glutamate, and PET scans with $\left[{ }^{11} \mathrm{C}\right] \mathrm{NNC} 112$ and $\left.{ }^{11} \mathrm{C}\right] \mathrm{FLB} 457$ were performed in these trained, habituated monkeys with an interval of at least $15 \mathrm{~h}$ after the last dose of MK-801. (+)-MK-801 was purchased from RBI (Natick,
MA, USA). FLB457 and the precursor of $\left[{ }^{11}\right.$ C]FLB457 were obtained from ABX (Dresden, Germany). NNC112, the precursor of $\left[{ }^{11} \mathrm{C}\right] \mathrm{NNC} 112$, were the kind gifts of Professor Christer Halldin of the Karolinska Institute, Stockholm, Sweden.

\section{Synthesis of ${ }^{11} \mathrm{C}$-Labeled Compounds}

Carbon-11 $\left({ }^{11} \mathrm{C}\right)$ was produced by a ${ }^{14} \mathrm{~N}(\mathrm{p}, \alpha){ }^{11} \mathrm{C}$ nuclear reaction using the cyclotron (HM-18, Sumitomo Heavy Industry, Tokyo, Japan) at Hamamatsu Photonics PET Center. The formed $\left[{ }^{11} \mathrm{C}\right] \mathrm{CO}_{2}$ was converted to $\left[{ }^{11} \mathrm{C}\right]$ methyl iodide via $\left[{ }^{11} \mathrm{C}\right]$ methane using the PET Trace MeI MicroLab method (GE Medical Systems, Milwaukee, Wis.). $\left[{ }^{11} \mathrm{C}\right] \mathrm{NNC} 112$ was labeled with ${ }^{11} \mathrm{C}$ by $\mathrm{N}$-methylation of its nor-compound with $\left[{ }^{11} \mathrm{C}\right]$ methyl iodide (Halldin et al, 1998). $\left[{ }^{11} \mathrm{C}\right] \mathrm{FLB} 457$ was labeled with ${ }^{11} \mathrm{C}$ by O-methylation of its nor-compound (Halldin et al, 1995). The radiochemical and chemical purities of the labeled compounds were greater than 98 and $99 \%$, respectively; their specific radioactivity ranged from 306 to $403 \mathrm{GBq} / \mu \mathrm{mol}$ for $\left[{ }^{11} \mathrm{C}\right] \mathrm{NNC} 112$, and from 348 to $372 \mathrm{GBq} / \mu \mathrm{mol}$ for $\left[{ }^{11} \mathrm{C}\right]$ FLB457. After chemical analysis for identification and purity, the solution was passed through a $0.22 \mu \mathrm{m}$ pore filter before i.v. administration to each monkey.

\section{PET Scans in Conscious Monkeys}

As described above, data were collected with a highresolution PET scanner. The transaxial resolution was $2.6 \mathrm{~mm}$ full-width at half-maximum (FWHM) and a centerto-center distance of $3.6 \mathrm{~mm}$ (Watanabe et al, 1997). The PET camera allowed 31 slices for imaging to be recorded simultaneously.

After an overnight fast, the trained and habituated animals were fixed by a skull mounted plastic cap to the monkey chair with stereotactic coordinates aligned parallel to the OM line. PET scans of the habituated and trained monkeys were performed in the conscious state (Tsukada et al, 1999a, b, 2000a, b, 2001a, b, 2002, 2004) in order to eliminate the effects of anesthetics. PET scans with $\left[{ }^{11} \mathrm{C}\right] \mathrm{NNC} 112$ and $\left[{ }^{11} \mathrm{C}\right] \mathrm{FLB} 457$ were performed in the 3D data acquisition mode for $64 \mathrm{~min}$ with six time frames at $10 \mathrm{~s}$ intervals, six frames at $30 \mathrm{~s}, 12$ frames at $1 \mathrm{~min}$, followed by 16 frames at $3 \mathrm{~min}$.

\section{PET Data Analysis}

Quantitative time-activity curves of radioactivity in the cerebellum were used as the input function because of its much lower density of DA receptors (Creese et al, 1975). Each ROI was fitted to a two-compartment model using the least-square fitting method to estimate the kinetic parameters $\left(K_{1}\right.$ and $\left.k_{2}\right)$. The distribution volume (DV) in each ROI was calculated as the ratio of $K_{1} / k_{2}$ (Lammertsma and Hume, 1996) as per the quantitative analysis of $\left[{ }^{11} \mathrm{C}\right] \mathrm{NNC} 112$ and $\left[{ }^{11} \mathrm{C}\right] \mathrm{FLB} 457$. In the present study, PET measurements were repeated frequently with 1 week intervals in the same monkey. It was not permitted by the Animal Ethical Committee to perform arterial blood sampling each time. Therefore, the reference tissue model 
analysis was selected instead of Logan graphic plots, or three-compartment modeling.

\section{Behavioral Tasks}

Behavioral task performance was evaluated as described previously (Inoue et al, 2004; Tsukada et al, 2004). Briefly, in the oculomotor delayed response (ODR) task, after a short intertrial interval (ITI), a small red spot $\left(0.1^{\circ}\right.$ in diameter) appeared as a fixation point at the center of a 15in monitor placed in front of the monkey $57 \mathrm{~cm}$ from its face. Each highly trained monkey was required to look at the fixation point and maintain fixation. The monkey's horizontal and vertical eye positions were recorded at $60 \mathrm{~Hz}$ by a monitoring system using an infrared camera (X-Y Tracer C3162, Hamamatsu Photonics, Hamamatsu, Japan). After the monkey maintained fixation for $1 \mathrm{~s}$, a red circle $\left(0.5^{\circ}\right.$ in diameter) was presented as a target cue for $100 \mathrm{~ms}$ (cue period), which was randomly presented at one of eight predetermined positions. Eccentricity was $5^{\circ}$ from the fixation point. The monkey was required to maintain fixation at the fixation point during the cue period and the subsequent $0.5-10 \mathrm{~s}$ delay period. At the end of the delay period, the fixation point was extinguished; the monkey was trained to make a saccade to the position where the target cue had been presented. If the monkey made a correct saccade within $500 \mathrm{~ms}$, it was rewarded with a drop of water.

In the visually guided saccade (VGS) task, after a short ITI, a fixation point appeared at the center of the monitor. The monkey was required to look at the fixation point and maintain it. After the monkey maintained fixation for $1 \mathrm{~s}$, the fixation point was extinguished and a target cue was presented at one of the eight predetermined positions. When the target cue was presented, the monkey had to make a saccade to the target cue within $500 \mathrm{~ms}$. ODR and VGS task data were obtained in 20 trials for each condition; the means $\pm S D$ were used for further data analysis.

In the single-dose acute study, $30 \mathrm{~min}$ before the beginning of the task saline or MK-801 in randomized doses of $0.03,0.1$, and $0.3 \mathrm{mg} / \mathrm{kg}$ was given i.v. Within $1-2$ weeks, the chronic daily bid study was begun. On the 7 th and 14th days after the beginning of daily MK-801 administration, behavioral analysis was performed prior to MK-801 administration. In the single acute and chronic bid MK-801 treatments, the delay period between cue presentation and saccade timing was fixed at $6 \mathrm{~s}$.

\section{Microdialysis Analysis}

A guide cannula was previously implanted $35 \mathrm{~mm}$ anterior to the intrameatal line and lateral $10 \mathrm{~mm}$ from the midline (A: 35, L: 10) according to the individual MR images. A microdialysis probe with a membrane region $250 \mu \mathrm{m}$ in diameter and $3 \mathrm{~mm}$ in length (Eicom A-I-8-03, Eicom, Tokyo, Kyoto) was inserted (only when scheduled) into the PFC ( $3.0 \mathrm{~mm}$ below the dura matter) of the monkey brain via the guide cannula. The probe was initially perfused with a modified Ringer solution (147 mM NaCl, $4 \mathrm{mM} \mathrm{KCl}$, $2.3 \mathrm{mM} \mathrm{CaCl}_{2}$, Otsuka Pharmaceutical, Tokyo, Japan) at a rate of $10 \mu \mathrm{l} / \mathrm{min}$ to remove overflow of neurotransmitters from the damaged tissue. The perfusion rate was decreased to $5 \mu \mathrm{l} / \mathrm{min} 2 \mathrm{~h}$ after insertion of the probe, $75 \mu \mathrm{l}$ samples were collected every $15 \mathrm{~min}$, and DA and glutamate contents were measured by HPLC systems (HTEC-500 and DTA-300, Eicom, Kyoto, Japan). These methods have been described previously by Tsukada et al (2000a, b).

In the single-dose MK-801 study, the mean data obtained from 0 to $120 \mathrm{~min}$ before administration of saline or MK801 were used as 'baseline'. Saline or MK-801 $(0.03,0.1$, and $0.3 \mathrm{mg} / \mathrm{kg}$ ) was administered $120 \mathrm{~min}$ after the beginning of sampling. The levels of glutamate and DA in the extracellular fluid (ECF) of PFC were expressed as '\% of baseline'. In the chronic study, only 'baseline' data were evaluated for 120 min during PET measurements on the 7 th and 14th days.

\section{Statistical Analysis}

Results were expressed as means \pm SD. Comparisons between the pretreatment 'baseline' and 'MK-801 administration' were carried out using a paired, two-tailed Student's $t$-test. A probability level of less than $5 \%(P<0.05)$ was considered significant.

\section{RESULTS}

Figures 1 and 2 illustrate the PET images and radioactivity uptake curves of $\left[{ }^{11} \mathrm{C}\right] \mathrm{NNC} 112$ and $\left[{ }^{11} \mathrm{C}\right] \mathrm{FLB} 457$ in the conscious monkey. High uptake was in the striatum. Medium uptake was in neocortical regions. Low uptake was in the cerebellum. This pattern is typical in normal monkey brain (Figure 1, 2a and b).

Quantitative kinetic analyses revealed that i.v. single-dose administration of MK-801 produced no significant changes in $\left[{ }^{11} \mathrm{C}\right] \mathrm{NNC1} 12$ binding to $\mathrm{D}_{1} \mathrm{R}$ in any cortical region in any dose (Figure 3a). In contrast, there was a dosedependent reduction in $\left[{ }^{11} \mathrm{C}\right] \mathrm{FLB} 457$ binding to $\mathrm{D}_{2} \mathrm{R}$ in the PFC, but not in the TMC or OCC after doses of $0.03,0.1$, and $0.3 \mathrm{mg} / \mathrm{kg}$ of $\mathrm{MK}-801$ (Figure $3 \mathrm{~b}$ ).

The effects of single doses of MK-801 on glutamate and DA extracellular concentrations in PFC ECF are shown in Figure 4. Baseline levels of glutamate and DA were

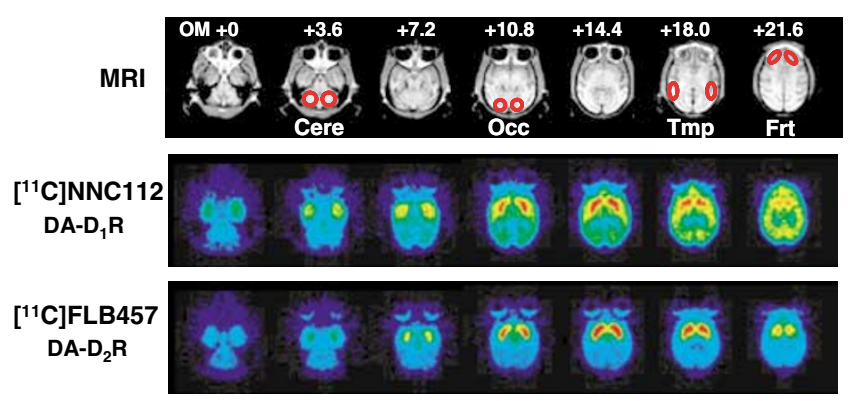

Figure I Typical MRI and PET brain images of [ ' $\mathrm{C}] \mathrm{NNCII}$ (a) and [ $\left.{ }^{1} \mathrm{C}\right] \mathrm{FLB} 457$ in the conscious rhesus monkeys (Macaca mulatta). MR images were obtained with a Toshiba MRT-50A/II (0.5 T). PET data were collected on a high-resolution PET scanner (Hamamatsu SHR-7700) with transaxial resolution of $2.6 \mathrm{~mm}$ (FWHM) and a center-to-center distance of $3.6 \mathrm{~mm}$. PET images were generated by summation of image data from 37 to $64 \mathrm{~min}$ after injection. The stereotactic coordinates of PET and MRI were adjusted based on the orbitomeatal (OM) line. Cere: cerebellum, Occ: occipital cortex. Tmp; temporal cortex, Frt; prefrontal cortex. Regions of interest (ROIs) are identified in the MRIs as illustrated. 

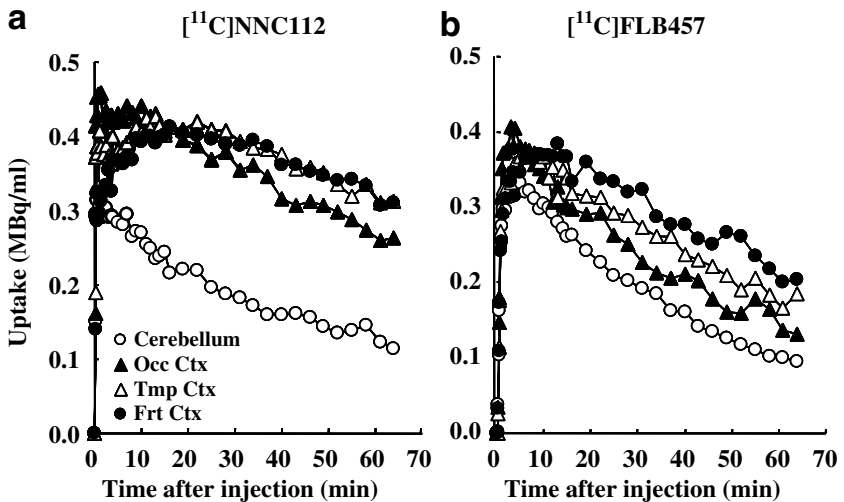

Figure 2 Typical time-activity brain uptake curves of [ ' $\mathrm{C}] \mathrm{NNCI} / 2$ (a) and ${ }^{11}$ C]FLB457 (b) in a conscious monkey. PET scans were begun immediately after i.v. injection of each tracer. Image data were collected for $64 \mathrm{~min}$. The ROls were the cerebellum, occipital (Occ Ctx), temporal (Tmp Ctx), and prefrontal cortices (Frt Ctx) selected from the MRI of the same animal. The radioactivity in each $\mathrm{ROI}$ is plotted against time after injection.

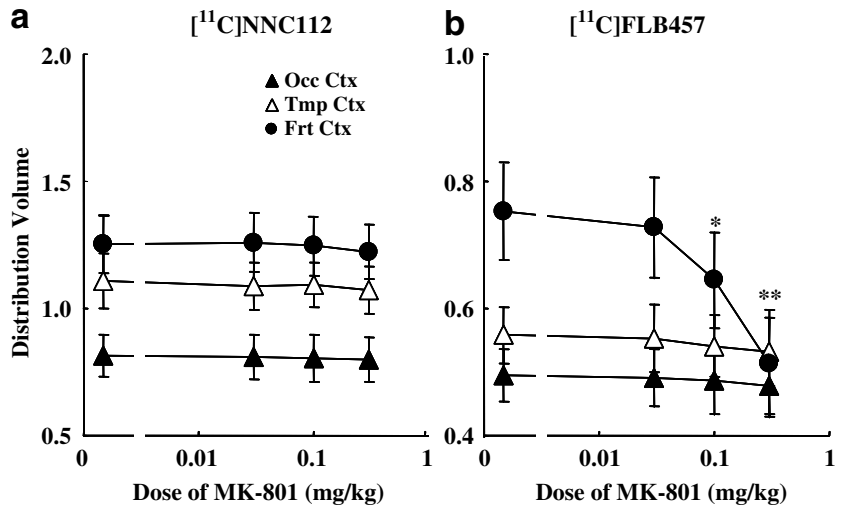

Figure 3 Effects of acute single-dose administration of MK-80I on binding of $\left[^{1} \mathrm{C}\right.$ C]NNCII2 (a) and $\left[^{11} \mathrm{C}\right] \mathrm{FLB} 457$ (b) in conscious monkey brains. MK-80I (0.03, 0.1 , and $0.3 \mathrm{mg} / \mathrm{kg})$ was administered i.v. just before tracer injection. Time-activity curves of radioactivity in the cerebellum and each ROI were fitted to a two-compartment model using the least-square method. The distribution volume $\left(\mathrm{DV}=K_{1} / \mathrm{k}_{2}\right)$ in each $\mathrm{ROI}$ was calculated. Each data point represents the mean and the vertical bars $( \pm S D)$ in this and subsequent figures. $N=8, * ; \quad P<0.05$ vs Dose $=0$, **; $P<0.01$ vs Dose $=0$.

$1.32 \pm 0.25$ and $0.52 \pm 0.07 \mathrm{fmol} / \mu \mathrm{l}$, respectively, in the PFC of conscious monkeys. When MK-801 was administered in doses of 0.03 and $0.1 \mathrm{mg} / \mathrm{kg}$, glutamate levels increased in PFC ECF (Figure 3a). In contrast, MK-801 in a large dose of $0.3 \mathrm{mg} / \mathrm{kg}$ produced conversely a slight reduction in extracellular glutamate levels in the PFC (Figure 4a). Administration of MK-801 (0.03, 0.1, and $0.3 \mathrm{mg} / \mathrm{kg})$ produced dose-dependent increases in the extracellular DA levels in PFC (Figure 4b).

With saline treatment, there were no significant delaydependent effects on VGS task performance. However, a delay-dependent reduction in the correct response was observed in ODR task performance, showing $79 \%$ accuracy at a 6-s delay period (Figure 5a). Single doses of MK-801 $(0.03,0.1$, and $0.3 \mathrm{mg} / \mathrm{kg})$ resulted in a dose-dependent impairment in the ODR task with a similar 6-s delay period.
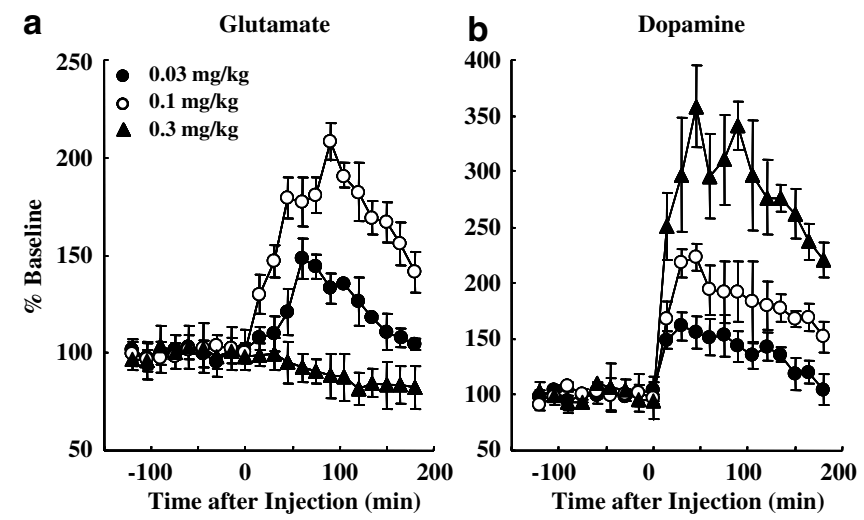

Figure 4 Effects of acute single-dose administration of MK-80I on glutamate (a) and DA (b) in the extracellular fluid (ECF) of prefrontal cortex (PFC) in conscious monkey brains. A microdialysis probe was inserted into the PFC region via a guide cannula. The probe was perfused with a modified Ringer solution at a rate of $5 \mu \mathrm{l} / \mathrm{min}$. Samples were collected every $15 \mathrm{~min}$. The glutamate and DA concentrations were measured by two separate HPLC systems. The averaged data obtained from 0 to $120 \mathrm{~min}$ without any infusion were used as 'baseline' data. MK$80 \mathrm{I}(0.03,0.1$, and $0.3 \mathrm{mg} / \mathrm{kg})$ was administered $120 \mathrm{~min}$ after the beginning of sampling (Time $=0$ ). The glutamate and DA levels were expressed as $\$$ baseline'.
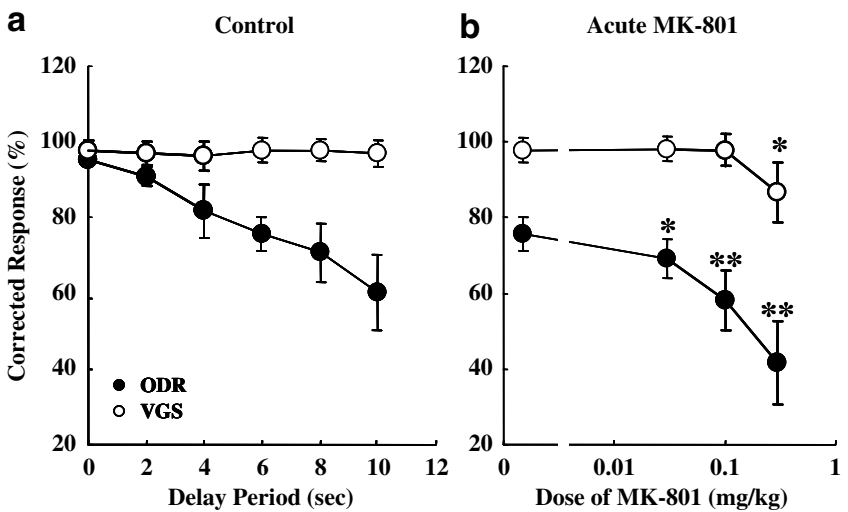

Figure 5 Effects of the central delay period (a) and acute single doses of MK-80 I (b) on working memory performance determined by oculomotor delayed response (ODR) and visually guided saccade (VGS) tasks in conscious monkeys. At 30 min before the start of each task, $0.9 \% \mathrm{NaCl}$ or MK-80I ( $0.03,0.1$, and $0.3 \mathrm{mg} / \mathrm{kg}$ ) was administered i.v. In the 'Control' condition (a), the delay period was randomly varied from 0.5 to $10 \mathrm{~s}$. In the 'MK-80I' condition, the delay period between cue presentation and saccade timing was fixed for $6 \mathrm{~s}$. *; $P<0.05$ vs Dose $=0$, **; $P<0.0$ I vs Dose $=0$.

There was no impairment on the VGS task in doses of 0.03 and $0.1 \mathrm{mg} / \mathrm{kg}$ (Figure 5b). A large dose of MK-801 (0.3 mg/ $\mathrm{kg}$ ) slightly impaired VGS task performance (Figure 5b). With this dose, glutamate concentrations in PFC ECF were decreased (Figure 4a).

During chronic daily bid treatment with MK-801 with a low dose of $0.03 \mathrm{mg} / \mathrm{kg}, \quad\left[{ }^{11} \mathrm{C}\right] \mathrm{NNC} 112$ binding to $\mathrm{D}_{1} \mathrm{R}$ significantly increased on the 14 th day in the PFC, but not in TMC and OCC (Figure 6a). In contrast, $\left[{ }^{11} \mathrm{C}\right]$ FLB457 binding to $\mathrm{D}_{2} \mathrm{R}$ showed no significant changes in any cortical regions on the 7 th day. There was a tendency to increase $\mathrm{D}_{2} \mathrm{R}$ binding, but this did not reach significance in 

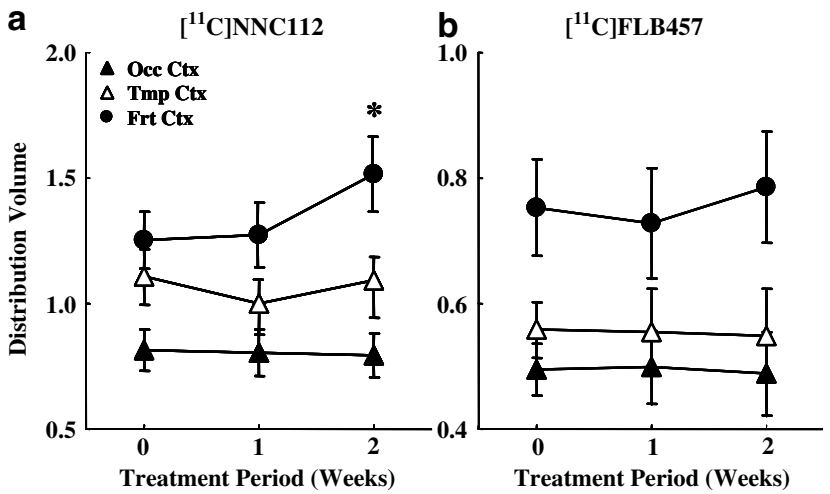

Figure 6 Effects of daily chronic administration of MK-80 I on binding of $\left[{ }^{1 /} \mathrm{C}\right] \mathrm{NNCl} / 2$ (a) and $\left[{ }^{1 /} \mathrm{C}\right] \mathrm{FLB} 457$ (b) in conscious monkey brain. MK$80 \mathrm{I}$ in a dose of $0.03 \mathrm{mg} / \mathrm{kg}$ was given i.m. b.i.d. for 13 days. On the 7th and 14th days, PET scans with $\left[{ }^{1} \mathrm{C}\right] \mathrm{NNCl} / 2$ and $\left[{ }^{1} \mathrm{C}\right] \mathrm{FLB} 457$ were performed with an interval of at least $15 \mathrm{~h}$ after the last dose of MK-80 I. Distribution volume $\left(D V=K_{1} / k_{2}\right)$ in each $\mathrm{ROI}$ was calculated as shown in Figure I. *; $P<0.05$ vs Dose $=0$.
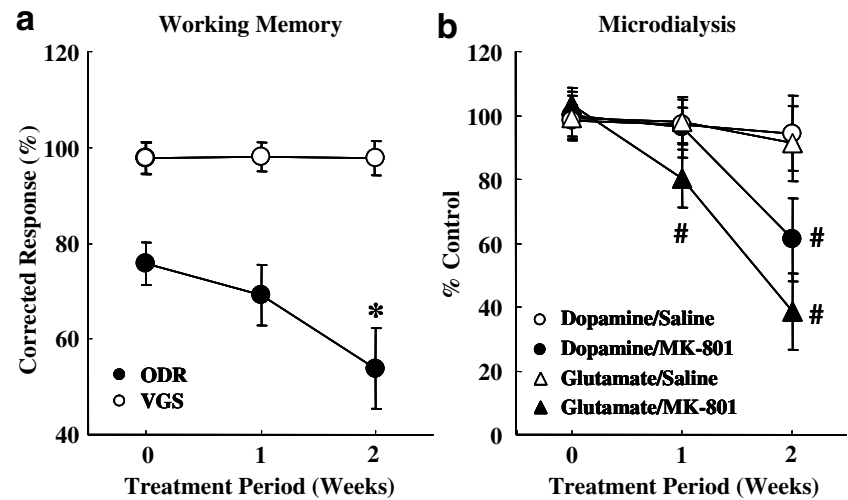

Figure 7 Effects of daily chronic administration of MK-80 I on working memory performance (a) and glutamate and DA levels in PFC (b). MK-80 I in a dose of $0.03 \mathrm{mg} / \mathrm{kg}$ was given i.m. b.i.d. for 13 days. On the 7th and 14th days, working memory task and microdialysis analyses were performed with an interval of at least I $5 \mathrm{~h}$ after the last dose of MK-80 I administration. *; $P<0.05$ vs dose $=0, \# ; P<0.0$ I vs corresponding saline condition.

PFC on the 14th day in this small group of monkeys (Figure 6b).

On the 14th day with chronic MK-801 administration, there were no significant changes in VGS task performance. In contrast, ODR task performance, with a 6-s delay period, showed marked impairment (Figure 7a).

As shown in Figure $7 \mathrm{~b}$, chronic daily bid injections of MK-801 produced a significant reduction in baseline glutamate levels on the 7th day, followed by decreased levels of both DA and glutamate on the 14th day.

To confirm a possible relationship between MK-801induced impairment of working memory performance and DA receptor function, ODR task performance was plotted against PFC DV of $\left[{ }^{11} \mathrm{C}\right]$ FLB457 (acute single doses) or $\left[{ }^{11} \mathrm{C}\right] \mathrm{NNC} 112$ (in chronic daily bid doses) in each animal (Figure 8). ODR task performance showed a positive correlation with $\left[{ }^{11} \mathrm{C}\right] \mathrm{FLB} 457$ binding to PFC $\mathrm{D}_{2}$ receptors after acute MK-801 treatment at $0.1 \mathrm{mg} / \mathrm{kg} \quad\left(r^{2}=0.705\right.$,

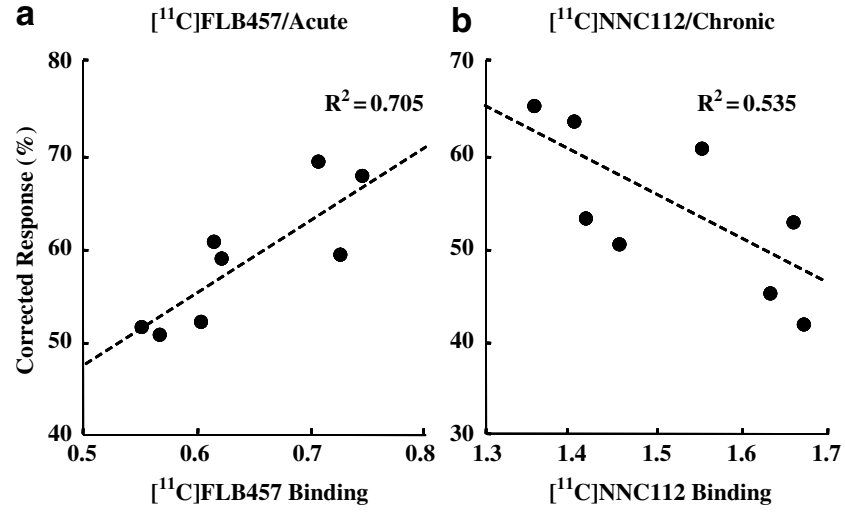

Figure 8 Relationship between MK-80I-induced impairment of working memory performance and $\mathrm{DA}_{2}$ (a) and $\mathrm{D}_{1}$ (b) receptor binding in the PFC of conscious monkeys. Working memory performance was evaluated with the ODR task with an acute dose of MK-80I of $0.1 \mathrm{mg} / \mathrm{kg}$ (a) and with chronic bid treatments for 13 days in a dose of $0.03 \mathrm{mg} / \mathrm{kg}$. ODR task performance was plotted against distribution volume $\left(=K_{1} / K_{2}\right)$ of [ ' C]FLB457 (a) or [ ' C]NNCII2 (b) in the PFC of each animal. Note the correlation of coefficients.

Figure 7a); with this dose, VGS task performance was not affected (Figure 5b). In contrast, an inverse correlation between ODR task performance and $\left[{ }^{11} \mathrm{C}\right] \mathrm{NNC} 112$ binding to the PFC $\mathrm{D}_{1}$ receptors was obtained in the PFC $\left(r^{2}=0.535\right)$ after daily bid MK-801 treatment for 2 weeks in a dose of $0.03 \mathrm{mg} / \mathrm{kg}$ (Figure $8 \mathrm{~b}$ ).

\section{DISCUSSION}

\section{The Role of DA/Glutamic Acid and Working Memory}

Working memory is impaired when DA is depleted in dorsolateral PFC of monkeys (Brozoski et al, 1979). Subsequently, Goldman-Rakic and Brown (1981) showed regional changes of monoamines in aging rhesus monkeys. Goldman-Rakic (1987) summarized the knowledge then available on the circuitry of the PFC and working memory mechanisms. Sawaguchi and Goldman-Rakic (1991) then showed that intracerebral injection of the $\mathrm{D}_{1} \mathrm{R}$ antagonist increased the error rate of a delayed response task. Another major advance was the discovery that the predominant mechanism of action of PCP, ketamine, and MK-801 was noncompetitive antagonism of the NMDA receptors of glutamic acid (Lodge et al, 1983; Thomson et al, 1985; Fagg, 1987). Acute administration of noncompetitive NMDA antagonists preferentially increase the release of DA in the PFC (Doherty et al, 1980; Deutch et al, 1987; Bowers and Morton, 1994; Hondo et al, 1994; Carlezon and Wise, 1996; Verma and Moghaddam, 1996; Jentsch et al, 1997a), probably through suppression of cortical NMDA-GABAergic synapses (Grunze et al, 1994; Yonezawa et al, 1998; Shi and Zhang, 2003) that normally inhibit DA release. It appears to be a paradox that typical psychomotor stimulants such as amphetamine (During et al, 1987) and cocaine (Sorg and Kalivas, 1993), noncompetitive NMDA receptor antagonists (Deutch et al, 1987; Bowers and Morton, 1994; Hondo et al, 1994; Carlezon and Wise, 1996; Verma and Moghaddam, 1996; Jentsch et al, 1997a), as 
well as acute stress (Murphy et al, 1996a,b) all induce impaired working memory performance via hyperdopaminergic neurotransmission. Those data indicate that activation of dopaminergic neurotransmission in the PFC also impairs working memory. The present microdialysis analysis indicates that DA levels in PFC were significantly increased by acute low-dose MK-801, but decreased after chronic treatment. The present ODR task performance results also demonstrate that both hyper (induced by acute MK-801 exposure)- and hypo (by chronic exposure)-DA transmission impairs working memory performance. Taken together, one can conclude that proper functioning of the DA system in PFC critically contributes to working memory. It has been reported that ketamine, a noncompetitive NMDA receptor antagonist, attenuates sensory perception (Oye et al, 1992), suggesting that the present data of impaired working memory performance by MK-801 might be produced by a general reduction or distortion of sensory input that affects the performance of any spatialrelated task. However, this is unlikely, because the doses of MK-801 used in the present study altered the ODR and not the VGS task, which does not involve a delay.

Morphological, biochemical, and pharmacological studies also have indicated a close interaction between excitatory amino acid and DA afferents in PFC. Dopaminergic and glutamatergic terminals are localized in close opposition to each other on the same postsynaptic pyramidal cell (Smiley et al, 1994). NMDA receptors are known to interact with the central dopaminergic system (Roberts and Anderson, 1979; Carter et al, 1988; Johnson and Jones, 1990; Krebs et al, 1991; Morari et al, 1993; Youngren et al, 1993; Tsukada et al, 2000b, 2001b). Furthermore, NMDA receptor antagonists reduce GABA release. In addition, glutamate release increase locally may stimulate DA release via non-NMDA receptors. Glutamate release may also occur as shifts between burst and nonburst firing of DA neurons. The DA innervation of PFC is considered to be highly responsive to psychomotor stimulants such as amphetamine (During et al, 1987), cocaine (Sorg and Kalivas, 1993), as well as NMDA receptor antagonists (Deutch et al, 1987; Bowers and Morton, 1994; Hondo et al, 1994; Carlezon and Wise, 1996; Verma and Moghaddam, 1996; Jentsch et al, 1997a).

\section{Prefrontal Cortical DA Receptor Changes Measured by PET}

Previous DA imaging studies with PET have been limited to the striatum due to the lack of suitable labeled compounds for the extrastriatal regions. These have a lower density of DA neuronal terminals compared to the striatum (Hall et al, 1988; Lidow et al, 1989). Recently, $\left[{ }^{11} \mathrm{C}\right] \mathrm{NNC1} 12$ (Halldin et $a l, 1998$ ) and $\left[{ }^{11} \mathrm{C}\right] \mathrm{FLB} 457$ (Halldin et al, 1995) have been developed to assess the extrastriatal $D_{1} R$ and $D_{2} R$, respectively, and were used in the present study. The results indicate that the acute administration of single doses of $\mathrm{MK}-801$ produced a dose-dependent reduction in $\left[{ }^{11} \mathrm{C}\right] \mathrm{FLB} 457$ binding to PFC $\mathrm{D}_{2} \mathrm{R}$, but not in the striatum. Perhaps kinetic and distribution issues are involved. One possible explanation for reduced binding in $\mathrm{PFC}$ might be competition between $\left[{ }^{11} \mathrm{C}\right]$ FLB457 and synaptic DA enhanced by NMDA inhibition based upon a conventional 'occupancy' theory. This is unlikely, however, because
Okauchi et al (2001) previously reported that methamphetamine did not affect $\left[{ }^{11} \mathrm{C}\right] \mathrm{FLB} 457$ binding to extrastriatal $\mathrm{D}_{2} \mathrm{R}$, suggesting the insensitivity of $\left[{ }^{11} \mathrm{C}\right] \mathrm{FLB} 457$ for synaptic DA, probably because of its high affinity to $D_{2} R$. Instead of the conventional 'occupancy' theory, another explanation may be a 'rate' theory defined as the dynamics of DA binding to receptors and the synaptic turnover of DA (Tsukada et al, 1999a, 2000a, b). Further studies are needed on the modulation of $\left[{ }^{11} \mathrm{C}\right] \mathrm{FLB} 457$ binding to extrastriatal $\mathrm{D}_{2} \mathrm{R}$. In contrast to $\mathrm{D}_{2} \mathrm{R}$, no significant changes in $\left[{ }^{11} \mathrm{C}\right] \mathrm{NNC} 112$ binding to PFC $\mathrm{D}_{1} \mathrm{R}$ were detected in the acute study. Although the different responses of both ligands to changes in endogenous DA should be taken into account, these results are consistent with the previous observation that impaired working memory performance by acute administration of noncompetitive antagonists of NMDA receptors is reversed by $\mathrm{D}_{2} \mathrm{R}$ antagonists, but not by $D_{1} R$ antagonists (Verma and Moghaddam, 1996).

Chronic administration of MK-801 in the present study elicited increased $\left[{ }^{11} \mathrm{C}\right] \mathrm{NNC} 112$ binding to PFC $\mathrm{D}_{1} \mathrm{R}$, but no significant change in $\left[{ }^{11} \mathrm{C}\right] \mathrm{FLB} 457$ binding to PFC $\mathrm{D}_{2} \mathrm{R}$. As previously reported, chronic administration of $\mathrm{PCP}$ reduces DA transmission in the PFC (Jentsch et al, 1997b, c); the present microdialysis data demonstrated lowered DA levels in PFC after repeated exposure to MK-801. Decreased DA neuronal activity might possibly contribute to the upregulation of $\mathrm{D}_{1} \mathrm{R}$ binding in PFC. In view of the differences between acute and chronic administration of NMDA antagonist treatment, one needs to consider alternative explanations.

\section{NMDA Antagonist Abuse, Schizophrenia, and Stress}

PCP has long been recognized as a useful drug model of schizophrenia (Luby et al, 1959, 1962; Snyder, 1980; Javitt and Zukin, 1991; Jentsch and Roth, 1999; Domino et al, 2004). The subsequent use of PCP and its shorter acting congener, ketamine, by substance abusers has made the former more difficult to study due to its DEA scheduled status. Chronic use of PCP produces robust and enduring cognitive deficits in humans (Cosgrove and Newell, 1991). Similarly, even single doses of ketamine produce reversible deficits in human cognition (Malhotra et al, 1996). These substances produce reduction of frontal cerebral blood flow reminiscent of schizophrenia (Weinberger et al, 1986). The extensive reviews by Bunney et al (1995), Meador-Woodruff and Kleinman (2002), and Krystal et al (2004) document the relationships between glutamate, NMDA antagonists, and schizophrenia. Krystal et al (1994) have been especially active in using subanesthetic doses of ketamine in normal volunteers as a drug model of schizophrenia. It is of interest that the effect of noncompetitive NMDA receptor antagonists on DA metabolism is greater in the mesocorticolimbic dopaminergic system than in the nigrostriatal dopaminergic system (Deutch et al, 1987; Rao et al, 1990). These modulations of PFC DA system are relevant to the psychotic effects of NMDA receptor antagonists. Some of these responses are, in part, inhibited by blocking dopaminergic transmission (Murray and Horita, 1978; Fessler et al, 1979). The role of the antagonistic effects of NMDA receptors has been of interest because of hypofunction of glutamatergic neurotransmission in the PFC (Carlsson et al, 1997), and its 
relationship to dopaminergic dysfunction (Robbins, 1990; Grace, 1991; Deutch, 1992), which has been hypothesized in schizophrenic patients. Recent PET studies have supported dysfunction of the extrastriatal dopaminergic system in schizophrenic patients (Okubo et al, 1997; Abi-Dargham et al, 2002; Suhara et al, 2002). The Okubo et al (1997) study demonstrated decreased $\mathrm{D}_{1} \mathrm{R}$ binding in PFC assayed with $\left[{ }^{11} \mathrm{C}\right] \mathrm{SCH} 23390$, while the Abi-Dargham et al (2002) study observed increased binding measured with $\left[{ }^{11} \mathrm{C}\right] \mathrm{NNC} 112$. The reasons for this discrepancy remained unclear until now, although the latter report correctly suggested the upregulation of PFC $\mathrm{D}_{1} \mathrm{R}$ binding induced by hypodopaminergic neuronal transmission. In $\left[{ }^{11} \mathrm{C}\right] \mathrm{FLB} 457$ binding to $\mathrm{D}_{2} \mathrm{R}$, Suhara et al (2002) reported decreased binding in the anterior cingulated cortex of schizophrenic patients, but not in PFC. The present results did not detect any changes in $\left[{ }^{11} \mathrm{C}\right] \mathrm{FLB} 457$ binding to $\mathrm{D}_{2} \mathrm{R}$, even in the anterior cingulate cortex (data not shown), perhaps due to the relatively short duration of chronic MK-801 treatment.

The PFC dopaminergic system is also vulnerable to stress. Chronic stress produces a marked reduction of DA transmission concomitant with an increase in $\mathrm{D}_{1} \mathrm{R}$ receptor density, resulting in working memory impairment. Both deficits in acquisition and maintenance of a novel shortterm memory occur in rats (Mizoguchi et al, 2000). These results suggest that the neuronal machinery by which noncompetitive NMDA receptor antagonists first activate DA transmission contributes to the development of longterm inhibition of dopaminergic neurons, resulting in cognitive deficits that occur after repeated administration of NMDA antagonists.

In conclusion, the present results demonstrate that either acute single dose or chronic daily doses of MK-801, which produce NMDA receptor inhibition, impair working memory performance with different levels of dopaminergic modulation as reflected by alterations in $D_{1} R$ and $D_{2} R$ binding in the PFC of conscious monkeys. These results suggest that proper functioning of the DA system in PFC is important for working memory-related mechanisms. Changes (either hyper- or hypoactivation) in the dopaminergic neuronal system in PFC probably contribute to the cognitive impairment observed in patients with neuropsychiatric diseases such as schizophrenia.

\section{ACKNOWLEDGEMENTS}

We are grateful to Ichiro Ando and Mitsuru Suzuki for their technical assistance. This work was supported in part by Grant-in-Aid for Creative Scientific Research of Japan Society for the Promotion of Science, and CREST, JST.

\section{REFERENCES}

Abi-Dargham A, Mawlawi O, Lombardo I, Gil R, Martinez D, Huang $\mathrm{Y}$ et al (2002). Prefrontal dopamine D1 receptors and working memory in schizophrenia. J Neurosci 22: 3708-3719.

Bowers MB, Morton JB (1994). Regional brain catecholamines and metabolites following THC, PCP and MK-801. Prog Neuropsychopharmacol Biol Psychiatry 18: 961-964.

Brozoski T, Brown R, Rosvold H, Goldman P (1979). Cognitive deficits produced by regional depletion of dopamine in prefrontal cortex of rhesus monkey. Science 205: 929-932.
Bunney BG, Bunney Jr WE, Carlsson A (1995). Schizophrenia and glutamate. In: Bloom FE, Kupfer DJ (eds). Psychopharmacology: The Fourth Generation of Progress. Raven Press Ltd: New York. pp 1205-1214.

Carlezon Jr WA, Wise RA (1996). Rewarding actions of phencyclidine and related drugs in nucleus accumbens shell and frontal cortex. J Neurosci 16: 1332-3122.

Carlsson A, Hanson LO, Waters N, Carlsson ML (1997). Neurotransmitter aberrations in schizophrenia: new perspectives and therapeutic implications. Life Sci 61: 75-94.

Carter CJ, L'Hereux, Scatton B (1988). Differential control by $\mathrm{N}$-methyl-D-aspartate and kainate of striatal dopamine release in vivo: a trans-striatal dialysis study. J Neurochem 51: 462-468.

Cosgrove J, Newell TG (1991). Recovery of neuropsychological functions during reduction in use of phencyclidine. J Clin Psychol 47: 159-169.

Creese I, Burt DR, Snyder SH (1975). Dopamine receptor binding: differentiation of agonist and antagonist states with $\left[{ }^{3} \mathrm{H}\right]$ dopamine and $\left[{ }^{3} \mathrm{H}\right]$ haloperidol. Life Sci 17: 993-1002.

Deutch AY (1992). The regulation of subcortical dopamine systems by the prefrontal cortex: interactions of central dopamine systems and the pathogenesis of schizophrenia. J Neural Transm Suppl 36: 61-89.

Deutch AY, Tam SY, Freeman AS, Bowers MB, Roth RH (1987). Mesolimbic and mesocortical dopamine activation induced by phencyclidine: contrasting pattern to striatal response. Eur J Pharmacol 134: 257-264.

Doherty JD, Simonovic M, So R, Meltzer HY (1980). The effect of phencyclidine on dopamine synthesis and metabolism in rat striatum. Eur J Pharmacol 65: 139-149.

Domino EF, Mirzoyan D, Tsukada H (2004). NMDA antagonists as drug models of schizophrenia: a surprising link to tobacco smoking. Prog Neuropsychopharmacol Biol Psychiat 28: 801-811.

During MJ, Bean AJ, Roth RH (1987). Effects of CNS stimulation on the in vivo release of the colocalized transmitters, dopamine and neurotensin, from rat prefrontal cortex. Neurosci Lett 140: $129-133$.

Fagg GE (1987). Phencyclidine and related drugs bind to the activated $N$-methyl-D-aspartate receptor-channels complex in rat brain membranes. Neurosci Lett 76: 221-227.

Fessler RG, Sturgeon RD, Meltzer HY (1979). Phencyclidineinduced locomotor activity in the rat is blocked by 6hydroxydopamine lesions of nucleus accumbens: comparison to other psychomotor stimulants. Psychopharmacology 82: 83-88.

Goldman-Rakic PS (1987). Circuitry of prefrontal cortex and the regulation of behavior by representational knowledge. In: Plum F, Mountcasle V (eds). Handbook of Physiology. American Physiological Society: Bethesda, MD. pp 373-412.

Goldman-Rakic PS, Brown RM (1981). Regional changes of monoamines in cerebral cortex and subcortical structure of aging rhesus monkeys. Neuroscience 6: 177-187.

Grace AA (1991). Phasic versus tonic dopamine release and the modulation of dopamine system responsibility: a hypothesis for the etiology of schizophrenia. Neuroscience 41: 1-24.

Grunze HCR, Rainnie DG, Hasselmo ME, Barkai E, Heam EF, McCarley RW et al (1994). NMDA-dependent modulation of CA1 local circuit inhibition. J Neurosci 16: 2034-2043.

Hall H, Farde L, Sedvall G (1988). Human dopamine receptor subtypes - in vitro binding analysis using ${ }^{3} \mathrm{H}-\mathrm{SCH} 23390$ and ${ }^{3}$ H-raclopride. J Neural Transm 73: 7-21.

Halldin C, Farde L, Högberg T, Mohell N, Hall H, Suhara T et al (1995). Carbon-11-FLB 457: a radioligand for extrastriatal $\mathrm{D}_{2}$ dopamine receptors. J Nucl Med 36: 1275-1281.

Halldin C, Foget C, Chou Y-H, Karlsson P, Swahn C-G, Sandell J et al (1998). Carbon-11-NNC112: a radioligand for PET examination of striatal and neocortical $\mathrm{D}_{1}$-dopamine receptors. J Nucl Med 39: 2061-2068. 
Hondo H, Yonezawa Y, Nakahara T, Nakamura K, Hirano M, Uchimura $\mathrm{H}$ et al (1994). Effects of phencyclidine on dopamine release in the rat prefrontal cortex; an in vivo microdialysis study. Brain Res 633: 337-342.

Inoue M, Mikami A, Ando I, Tsukada H (2004). Functional brain mapping of the macaque related to spatial working memory as revealed by PET. Cereb Cortex 14: 106-119.

Javitt DC, Zukin SR (1991). Recent advances in phencyclidine model of schizophrenia. Am J Psychiat 148: 1301-1308.

Jentsch JD, Elsworth JD, Redmond Jr DE, Roth RH (1997a). Phencyclidine increases forebrain monoamine metabolism in rats and monkey: modulation by the isomers of HA966. J Neurosci 17: 1769-1775.

Jentsch JD, Redmond Jr DE, Elsworth JD, Taylor JR, Youngren KD, Roth RH (1997b). Enduring cognitive deficits and cortical dopamine dysfunction in monkeys after long-term administration of phencyclidine. Science 277: 953-955.

Jentsch JD, Roth RH (1999). The neuropsychopharmacology of phencyclidine: from NMDA receptor hypofunction to the dopamine hypothesis of schizophrenia. Neuropsychopharmacology 20: 201-225.

Jentsch JD, Tran A, Le D, Youngren KD, Roth RH (1997c). Subchronic phencyclidine administration reduces mesofrontal dopamine utilization and impairs prefrontal cortical-dependent cognition in the rat. Neuropharmacology 17: 92-99.

Johnson KM, Jones SM (1990). Neuropharmacology of phencyclidine: a therapeutic potential. Ann Rev Pharmacol Toxicol 30: 707-750.

Krebs MO, Desce JM, Kemel ML, Gauchy C, Godeheu G, Cheramy A et al (1991). Glutamatergic control of dopamine release in the rat striatum: evidence for presynaptic $N$-methyl-D-aspartate receptors on dopaminergic nerve terminals. J Neurochem 56: 81-85.

Krystal JH, Abi-Dargham A, Larulle M, Moghaddam B (2004). Pharmacological models of psychoses(Chapter 21). In: Charney DS, Nestler (eds). Neurobiology of Mental Illness, 2nd edn. Oxford University Press: New York. pp 287-298.

Krystal JH, Karper LP, Seibyl JP, Freeman GK, Delaney R, Bremner JD et al (1994). Subanesthetic effects of the noncompetitive NMDA antagonist, ketamine, in humans: psychotomimetic, perceptional, cognitive and neuroendocrine response. Arch Gen Psychiatry 51: 199-214.

Lammertsma A, Hume S (1996). Simplified reference tissue model for PET receptor studies. Neuroimage 4: 153-158.

Lidow MS, Goldman-Rakic PS, Rakic P, Innis RB (1989). Dopamine $\mathrm{D}_{2}$ receptors in the cerebral cortex: distribution and pharmacological characterization with $\left[{ }^{3} \mathrm{H}\right]$ raclopride. Proc Natl Acad Sci USA 86: 6412-6416.

Lodge D, Berry SC, Burton NR (1983). Arylcyclohexylamines selectively reduce excitation of mammalian nerones by aspartate-like amino acids. In: Kamenka JM, Domino EF, Geneste P (eds). Phencyclidine and Related Arylcyclohexylamines: Present and Future Applications. NPP Books: Ann Arbor. pp 595-616.

Luby ED, Cohen BD, Rosenbaum G, Gottlieb JS, Kelly R (1959). Study of a new schizophrenomimetic drug-Sernyl. Arch Neurol Psychiat 81: 363-369.

Luby ED, Gottlieb JS, Cohen BD, Rosenbaum G, Domino EF (1962). Model psychoses and schizophrenia. Am J Psychiatry 118: $61-67$

Malhotra AK, Pinals DA, Weingartner H, Sirocco K, Missar CD, Pickar D et al (1996). NMDA receptor function and human cognition: the effects of ketamine in healthy volunteers. Neuropsychopharmacology 14: 301-307.

Meador-Woodruff JH, Kleinman JE (2002). Neurochemistry of schizophrenia: glutamatergic abnormalities. In: David KL, Charney D, Coyle JT, Nemeroff C (eds). The Fifth Generation of Progress. Lippincott Williams \& Wilkins: Philadelphia. pp 717-728.
Mizoguchi K, Yuzurihara M, Ishige A, Sasaki H, Chui DH, Tabira T (2000). Chronic stress induces impairment of spatial working memory because of prefrontal dopaminergic dysfunction. J Neurosci 20: 1568-1574.

Morari M, O'Connor T, Ungerstedt U, Fuxe K (1993). N-methyl-Daspartic acid differentially regulates extracellular dopamine, GABA and glutamate levels in the dorsolateral neostriatum of the halothane-anesthetized rat: an in vivo microdialysis study. J Neurochem 60: 1884-1893.

Murphy BL, Arnsten AFT, Goldman-Rakic PS, Roth RH (1996a). Increased dopamine turnover in the prefrontal cortex impairs spatial working memory performance in rats and monkeys. Proc Natl Acad Sci USA 93: 1325-1329.

Murphy BL, Arnsten AFT, Jentsch JD, Roth RH (1996b). Dopamine and spatial working memory in rats and monkeys: pharmacological reversal of stress-induced impairment. J Neurosci 16: $7768-7775$.

Murray TF, Horita A (1978). Phencyclidine-induced stereotyped behavior in rats: dose-response effects and antagonism by neuroleptics. Life Sci 24: 2217-2226.

Okauchi T, Suhara T, Maeda J, Kawabe K, Ohbayashi S, Suzuki K (2001). Effect of endogenous dopamine on extrastriatal $\left[{ }^{11} \mathrm{C}\right]$ FLB457 binding measured by PET. Synapse 41: 87-95.

Okubo Y, Suhara T, Suzuki K, Kobayashi K, Inoue O, Terasaki O et al (1997). Decreased prefrontal dopamine $\mathrm{D}_{1}$ receptors in schizophrenia revealed by PET. Nature 386: 634-636.

Oye N, Paulsen O, Maurset A (1992). Effects of ketamine on sensory perception: evidence for a role of $N$-methyl-D-aspartate receptors. J Pharmacol Exp Ther 260: 1209-1213.

Rao TS, Kim HS, Lehmann J, Martin LL, Wood PL (1990). Selective activation of dopaminergic pathways in the mesocortex by compounds that act at phencyclidine (PCP) binding site: tentative evidence for PCP recognition sites not coupled to $\mathrm{N}$-methyl-D-aspartate (NMDA) receptors. Neuropharmacology 29: 225-230.

Robbins TW (1990). The case for frontostriatal dysfunction in schizophrenia. Schizophr Bull 16: 391-402.

Roberts PJ, Anderson SD (1979). Stimulatory effect of L-glutamate and related amino acids on $\left[{ }^{3} \mathrm{H}\right]$ dopamine release from rat striatum: an in vitro model for glutamate actions. J Neurochem 32: 1539-1545.

Sawaguchi T, Goldman-Rakic PS (1991). D1 dopamine receptors in prefrontal cortex: involvement in working memory. Science 251: 947-950.

Shi W-X, Zhang X-X (2003). Dendritic glutamate-induced bursting in the prefrontal cortex: further characterization and effects of phencyclidine. J Pharmacol Exper Ther 305: 680-687.

Smiley JF, Levey A, Ciliax B, Goldman-Rakic PS (1994). D1 dopamine receptor immunoreactivity in human and monkey cerebral cortex: predominant and extrasynaptic localization in dendritic spines. Proc Natl Acad Sci USA 91: 5720-5724.

Snyder SH (1980). Phencyclidine. Nature 285: 355-358.

Sorg BA, Kalivas PW (1993). Effects of cocaine and footshock stress on extracellular dopamine levels in the medial prefrontal cortex. Neuroscience 53: 695-703.

Suhara T, Okubo Y, Yasuno F, Sudo Y, Inoue M, Ichiyama T et al (2002). Decreased dopamine $D_{2}$ receptor binding in the anterior cingulate cortex in schizophrenia. Arch Gen Psychiatry 59: 25-30.

Thomson AM, West DC, Lodge D (1985). An N-methyl-D-aspartate receptor-mediated synapse in rat cerebral cortex: a site of action of ketamine? Nature 313: 479-481.

Tsukada H, Harada N, Nishiyama S, Ohba H, Kakiuchi T (2000a). Cholinergic neuronal modulation alters dopamine $\mathrm{D}_{2}$ receptor availability in vivo by regulating receptor affinity induced by facilitated synaptic dopamine turnover: PET studies with microdialysis in the conscious monkey brain. J Neurosci 20: 7067-7073. 
Tsukada H, Harada N, Nishiyama S, Ohba H, Sato K, Fukumoto D et al (2000b). Ketamine decreased striatal $\left[{ }^{11} \mathrm{C}\right]$ raclopride binding with no alterations in static dopamine concentrations in the striatal extracellular fluid in the monkey brain: multiparametric PET studies combined with microdialysis analysis. Synapse 37: 95-103.

Tsukada H, Harada N, Ohba H, Nishiyama S, Kakiuchi T (2001a). Facilitation of dopaminergic neural transmission does not affect $\left[{ }^{11} \mathrm{C}\right] \mathrm{SCH} 23390$ binding to the striatal $\mathrm{D}_{1}$ dopamine receptors, but the facilitation enhances phosphodiesterase type-IV activity through $\mathrm{D}_{1}$ receptors: PET studies in the conscious monkey brain. Synapse 42: 258-265.

Tsukada H, Miyasato K, Kakiuchi T, Nishiyama S, Harada N, Domino EF (2002). Comparative effects of methamphetamine and nicotine on the striatal $\left[{ }^{11} \mathrm{C}\right]$ raclopride binding in unanesthetized monkeys. Synapse 45: 207-212.

Tsukada H, Nishiyama S, Fukumoto D, Ohba H, Sato K, Kakiuchi $\mathrm{T}$ (2004). Effects of acute acetylcholinesterase inhibition on the cerebral cholinergic neuronal system and cognitive function: functional imaging of the conscious monkey brain using animal PET in combination with microdialysis. Synapse 52: 1-10.

Tsukada H, Nishiyama S, Kakiuchi T, Ohba H, Sato K, Harada N (1999a). Is synaptic dopamine concentration the exclusive factor which alters the in vivo binding of $\left[{ }^{11} \mathrm{C}\right]$ raclopride? PET studies combined with microdialysis in conscious monkeys. Brain Res 841: $160-169$.
Tsukada H, Nishiyama S, Kakiuchi T, Ohba H, Sato K, Harada N (2001b). Ketamine alters the availability of striatal dopamine transporter as measured by $\left[{ }^{11} \mathrm{C}\right] \beta-\mathrm{CFT}$ and $\left[{ }^{11} \mathrm{C}\right] \beta$-CIT-FE in the monkey brain. Synapse 42: 273-280.

Tsukada H, Nishiyama S, Kakiuchi T, Ohba H, Sato K, Harada N et al (1999b). Isoflurane anesthesia enhances the inhibitory effects of cocaine and GBR12909 on dopamine transporter: PET studies in combination with microdialysis in the monkey brain. Brain Res 849: 85-96.

Verma A, Moghaddam B (1996). NMDA receptor antagonists impair prefrontal cortex function as assessed via spatial delayed alternation performance in rats: modulation by dopamine. J Neurosci 16: 373-379.

Watanabe M, Okada H, Shimizu K, Omura T, Yoshikawa E, Kosugi $\mathrm{T}$ et al (1997). A high resolution animal PET scanner using compact PS-PMT detectors. IEEE Trans Nucl Sci 44: 1277-1282.

Weinberger DR, Berman KF, Zee RF (1986). Physiologic dysfunction of dorsolateral prefrontal cortex in schizophrenia, I: regional cerebral blood flow evidence. Arch Gen Psychiatry 43: 114-124.

Yonezawa Y, Kuroki T, Kawahara T, Tashiro N, Uchimura H (1998). Involvement of $\gamma$-aminobutyric acid neurotransmission in phencyclidine-induced dopamine release in the medial prefrontal cortex. Eur J Pharmacol 341: 45-56.

Youngren KD, Daly DA, Moghaddam B (1993). Distinct action of endogenous excitatory amino acids on the outflow of dopamine in the nucleus accumbens. J Pharmacol Exp Ther 264: 289-293. 